University of South Florida

DIGITAL COMMONS

Digital Commons @ University of

@ UNIVERSITY OF SOUTH FLORIDA

South Florida

School of Geosciences Faculty and Staff

Publications

School of Geosciences

10-1987

\title{
Eruptions of Pavlof Volcano and their Possible Modulation by Ocean Load and Tectonic Stresses
}

Stephen R. McNutt

Columbia University, smcnutt@usf.edu

R. J. Beavan

Columbia University

Follow this and additional works at: https://digitalcommons.usf.edu/geo_facpub

Part of the Earth Sciences Commons

\section{Scholar Commons Citation}

McNutt, Stephen R. and Beavan, R. J., "Eruptions of Pavlof Volcano and their Possible Modulation by Ocean Load and Tectonic Stresses" (1987). School of Geosciences Faculty and Staff Publications. 258.

https://digitalcommons.usf.edu/geo_facpub/258

This Article is brought to you for free and open access by the School of Geosciences at Digital Commons @ University of South Florida. It has been accepted for inclusion in School of Geosciences Faculty and Staff Publications by an authorized administrator of Digital Commons @ University of South Florida. For more information, please contact digitalcommons@usf.edu. 
ERUPTIONS OF PAVLOF VOLCANO AND THEIR POSSIBLE MODULATION BY OCEAN LOAD AND TECTONIC STRESSES

S. R. McNutt 1,2 and R. J. Beavan

Lamont-Doherty Geological Observatory of Columbia University, Palisades, New York

Abstract. All nine magmatic eruptions at Pavlof Volcano in six of the years from 1973 to 1984 have occurred between september 9 and November 20. Volumes of erupted material range from 0.1 to $15.9 \times 10^{6} \mathrm{~m}^{3}$ (dense rock equivalent) at an average rate of $\sim 3 \times 10^{6}$ $\mathrm{m}^{3} \mathrm{yr}^{-1}$. The volumes are estimated from eyewitness reports for two eruptions; the others are estimated from a relationship that we derive between eruption volume and harmonic tremor duration and amplitude. The volume of lava erupted is approximately time predictable. A significant correlation exists between the eruptions and yearly nontidal variations in sea level and may result from ocean loading. Calculated volume changes beneath the volcano due to ocean loading are from 0.02 to 2 times eruption volumes, and we postulate that the volcano acts as a long-period (several month) volume strain meter, with lava being preferentially erupted when strain beneath the volcano is compressive. The volcano did not erupt during the period 1978-1980, when tilt, seismic data, and sea level data indicate that deep aselsmic slip may have occurred. Models of this event predict a volume increase beneath the volcano that might have compensated strain from magma injection. These observations indicate that pavlof Volcano may be responsive to small, slow changes in ambient stresses or strains and that these changes may modify or trigger eruptions.

\section{Introduction}

Pavlof Volcano (latitude $55^{\circ} 24^{\prime} \mathrm{N}$, longitude $\left.161^{\circ} 54^{\prime} \mathrm{W}\right)$ is a $2518-\mathrm{m}-\mathrm{high}$ stratovolcano which sits on the Alaska Peninsula roughly in the middle of the Shumagin seismic gap, as identified by sykes et al. [1981] (Figure 1). Pavlof is the most persistently active volcano in North America, with over 38 reports of activity and 29 documented eruptions since it = was first sighted by Russian explorers in the $1760 \mathrm{~s}$ [McNutt, 1985; Simkin et al., 1981]. In 1973 Lamont-Doherty Geological Observatory installed a seismic network in the shumagins, including one station near pavlof volcano, jointly operated with the University of Alaska.

\footnotetext{
$\mathbf{1}_{\text {Also }}$ at Department of Geological sciences, Columbia University, New York.

$2_{\text {Now at California Division of Mines and }}$ Geology, Sacramento.
}

Copyright 1987 by the American Geophysical Union.

Paper number $5 B 5578$.

$0148-0227 / 87 / 005 B-5587 \$ 05.00$
In 11 years of seismic monitoring (1973-1984), nine major eruptions and approximately 13 minor eruptions have occurred (Table 1). All of the major eruptions occurred between September 9 and November 20, and four of them in four different years occurred in the same 4-day period between November 11 and 15. This nonrandom temporal clustering of activity provided a major impetus for the present study. We have examined all available geophysical data for the shumagin Islands/Pavlof region, and in this report we present a synthesis of the volcano's behavior with respect to its tectonic setting. It is shown that yearly, nontidal variations in sea level correlate well with the eruption times and that compressional strains due to increased ocean loading during fall and winter cause volume changes beneath the volcano that are from 28 to $200 \%$ of the erupted lava volumes. We speculate that sea level variations modulate the eruption rate.

A near cessation of activity of any kind at the volcano occurred during 1977-1979. This period preceded and over lapped a reversal of ground tilt in the shumagins between 1978 and 1980 [Beavan et al., 1983, 1984] and the occurrence of a higher than usual number of deep, moderately large earthquakes to the NE of pavlof. We infer that the anomalous seismicity and tilt are causally related and use the epicenters of the large, deep events along with other information to help constrain a model of deep aseismic slip beneath the area [Beavan et al., 1984]. This model is used to calculate dilatational volume strains beneath Pavlof volcano. We show that the resulting volume change agrees fairly well with the volume of lava which is normally erupted during a 3-year period. This provides further evidence for a modulation of eruption rate by applied stresses.

We discuss these results in the context of long-term growth of the volcano and of the volcano's usefulness as a "volume strain meter" to monitor changing tectonic conditions in the shumagin seismic gap. While only the sea level and tilt reversal effects are modeled quantitatively, we suggest that other mechanisms with similar periods and amplitudes also affect stresses and strains beneath the volcano and hence may modify Pavlof's eruptive activity.

\section{Volcanic Activity}

The activity of the volcano is compiled chiefly from seismic records. The number of seismic events per day are counted for three different types of events: B-type events (those with emergent onsets, no clear $S$ phase, and a frequency content of approximately $1.5 \mathrm{~Hz}$ [Minakami, 1960], explosion earthquakes (similar to the B-type events but with a distinct air shock phase), and tremor (a continuous signal on 


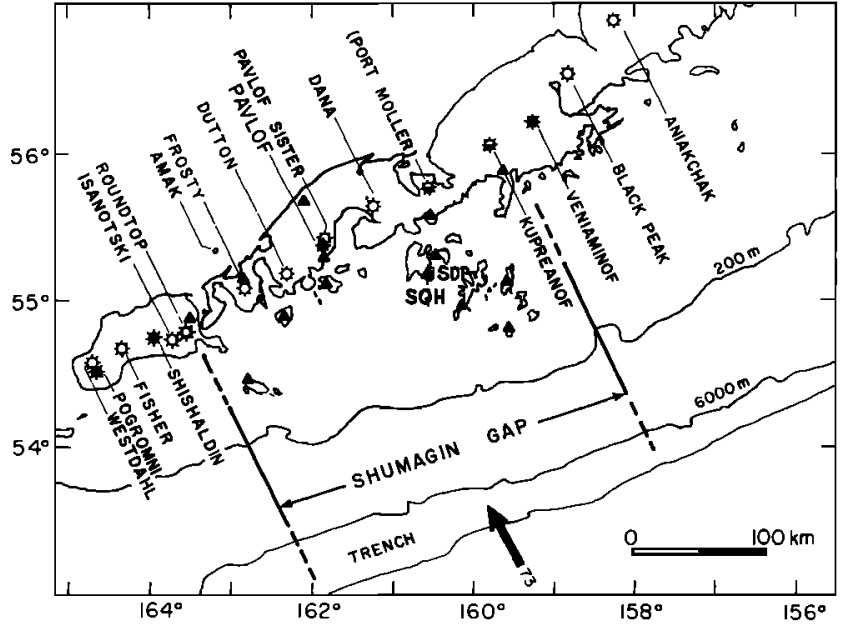

Fig. 1. Index map of the study area. Active (Holocene) volcanoes are shown as sunbursts; solid symbols mark volcanoes that have erupted in the past 10 years, while half solid symbols mark volcanoes that have had earthquake swarms or geothermal activity (e.g., steaming). Triangles denote seismic stations. The boundaries of the Shumagin seismic gap ( $K$. Jacob, personal communication, 1984) are shown as solid lines for the seismogenic portion of the rupture zone and as dashed lines for nonseismic portions. The arrow shows the plate convergence rate in $\mathrm{mm} \mathrm{yr}^{-1}$ [from Minster and Jordan, 1978]. SDP and SQH are the sites of the level lines whose data are plotted in Figure 7 .

a time scale of minutes to hours with a frequency content similar to both the B-type events and ground waves of the explosions, about $1.5 \mathrm{~Hz})$. Detailed descriptions and analyses of these events can be found in the work by McNutt [1985, 1986].

Plots in Figure 2 show the number of B-type events and explosions per day. Horizontal bars above the data indicate time periods during which explosion earthquakes were recorded. Explosion earthquakes are defined by unambiguous evidence (the air wave) of explosions near the volcano's summit. As many as 13 explosions per hour have been recorded, and in general, the number of explosions per unit time increases rapidly, then decays exponentially with time. During the explosive eruptions for which we have visual reports, small clouds of steam and ash are sometimes observed [e.g., Sventek, 1975]. Many of the explosive eruptions, while producing clear, unambiguous explosion earthquakes, produce so little ash that independent visual observations are not reported. Solid circles above the data indicate tremor episodes during which magmatic eruptions occurred. Every episode of high-amplitude volcanic tremor recorded since 1973 has accompanied a magmatic eruption with lava fountaining and voluminous ash ejection to heights of $11 \mathrm{~km}$ or more. This suggests that the seismic data might be used to infer the eruptive activity of Pavlof Volcano. The seismic data, which are quantitative, of high quality, and not affected by darkness or cloud cover, have been carefully compared with the few observations of volumes of eruptive material to infer a relation between tremor amplitude and duration and eruptive volume for eruptions during the time period 1973-1984.

Pavlof has had nine magmatic and 13 explosive eruptions between 1973 and 1984 (Figure 2 and Table 1). From a background level of between 0 and about 50 B-type events per day, seismicity generally increases by a factor of 3 or more during the explosive eruptions. During the magmatic eruptions, strong volcanic tremor is seen on the seismograms, and individual B-type events or explosions cannot be distinguished. Seismicity counted on the basis of tremor duration plus individual events [McNutt, 1985] shows about 2000-2500 events per day. The terms "magmatic" and "explosive" are used only for descriptive purposes to distinguish between the obvious seismic and eruptive characteristics. The explosive eruptions, however, do involve magma and thus may be magmatic, phreatomagmatic, or both.

\section{Volume Estimates for 1980 and 1981 Eruptions}

We have the most complete eruption data for the September 1981 major eruption; to summarize (see the appendix for details), it produced approximately $1.0-1.7 \times 10^{7} \mathrm{~m}^{3}$ of ash, $4.8-5.6 \times 10^{6} \mathrm{~m}^{3}$ of lava as a rootless lava flow of basaltic-andesite $\left(53.48 \mathrm{SiO}_{2}\right)$, an eruption cloud to a height of $11 \mathrm{~km}$, and 30 continuous hours of high-amplitude volcanic tremor at a frequency of about $1.5 \mathrm{~Hz}$ (see Figure 3 ). The lava volume estimates were made from analysis of photographs, pilot reports, and a visit 1 week after the eruption by a field crew. The estimated lava volume for the November 1980 eruption, also based on analysis of photographs and pilot reports (see the appendix), is about $1.2-2.8 \times 10^{6} \mathrm{~m}^{3}$, and we infer an ash volume of $2.0-8.0 \times 10^{6} \mathrm{~m}^{3}$.

Because the 1980 and 1981 eruptions showed similarities in plume heights, total durations, lava fountaining, lava flows, and volcanic tremor, we judge that the two eruptions are quite similar to each other. Assuming therefore that the ratio of lava to ash volume is the same, we estimate ash volume for the November 1980 eruption to be $2.0-8.0 \times 10^{6} \mathrm{~m}^{3}$ based on the measurements and errors of the September 1981 ash. For both the 1980 and 1981 eruptions, ash density is assumed to be $1100 \mathrm{~kg} \mathrm{~m}^{-3}$ [e.g., Rose et al., 1978] compared with $2700 \mathrm{~kg}$ $\mathrm{m}^{-3}$ for lava; the dense rock equivalent is obtained by multiplying the ash volume by $11 / 27$ $=0.41$. Thus the total equivalent dense rock volumes for the 1980 and 1981 eruptions are $2.0-6.1 \times 10^{6} \mathrm{~m}^{3}$ and $8.8-12.7 \times 10^{6} \mathrm{~m}^{3}$, respectively.

\section{Volume Estimates for Other Eruptions}

At Pavlof, the tremor amplitude is generally highest when the height of lava fountaining is greatest [McNutt, 1985]. Also, the total duration of Pavlof tremor episodes agrees well with the duration of observed eruptive activity. We use these and other facts to suggest that ejecta volumes for those eruptions that lack field observations may be estimated from the seismic data. For tremor duration $T$ 
TABLE 1. List of Pavlof Volcano Eruptions, 1973-1983, Deduced From Seismicity

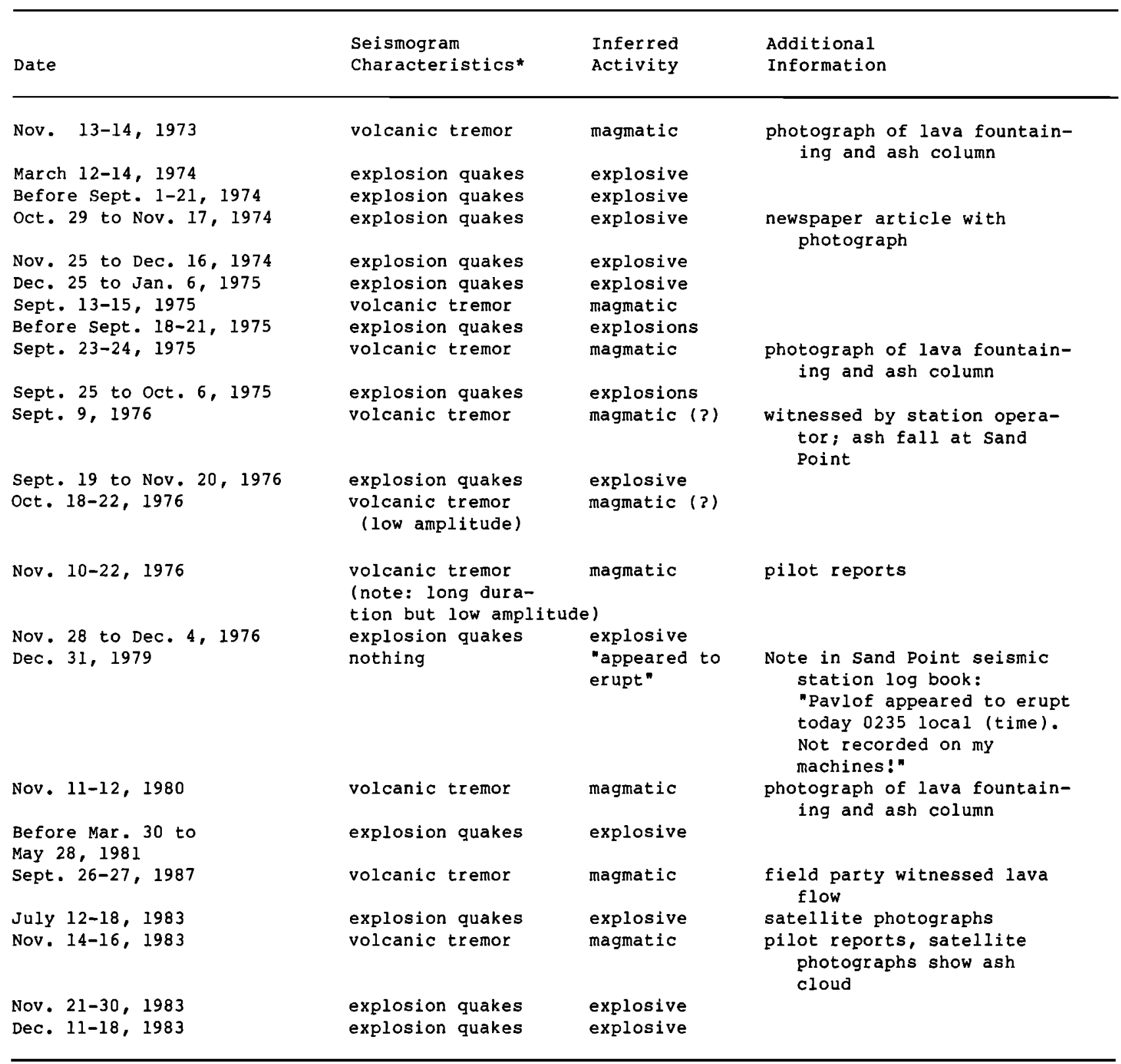

*B-type earthquakes always occur but in higher numbers during eruptions.

and average tremor amplitude $A$, we suggest that volume $V$ may be estimated by $\mathrm{V} \alpha$ AT or $\mathrm{V} \alpha$ $\mathrm{A}^{2} \mathrm{~T}$. Either estimate is reasonably consistent with the 1980 and 1981 data, and these are used to derive the proportionality constant from which the 1973-1976 and 1983 eruption volumes are estimated (Table 2). Episodes of tremor do sometimes occur with no observed eruptive activity at Pavlof, but these tremor episodes are generally between 2- and 26-min duration, which is much less than the 2.5- to >56-hour durations for the tremor episodes shown in Figure 3. Also, a few longer (hours) duration tremor episodes have been recorded with no directly observed eruptive activity, but these are either of low amplitude or occur within a few days after confirmed magmatic eruptions.
All the confirmed magmatic eruptions produced volcanic tremor with both long duration and high amplitude. This fact and the similarities in types of activity, heights of lava fountaining, heights of steam and ash clouds, and durations of eruptions form the basis for deriving volume estimates from the seismic data.

\section{Correlations of Eruptions With} Other Geophysical Data

A systematic search was made by visually comparing time series to find if any correlation existed between the eruptions and each of the following: (1) atmospheric pressure, (2) earth and ocean-load tides, (3) long-period sea level, (4) shallow seismicity $(<50 \mathrm{~km})$, (5) deep 


\section{PAVLOF VOLCANO SEISMICITY}
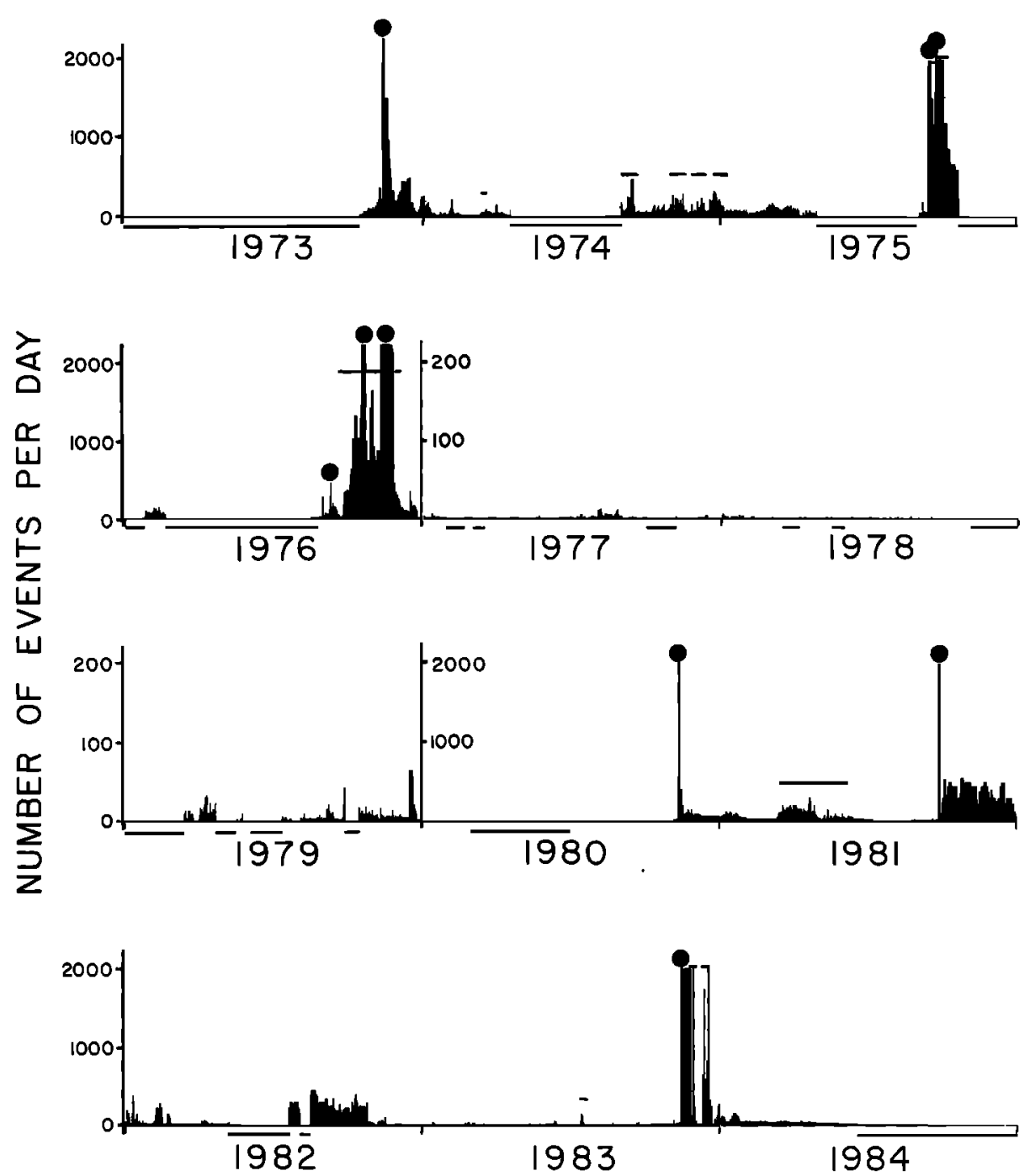

Fig. 2. Plots of the number of B-type volcanic earthquakes and explosions per day for the time period October 1973 to June 1984. Magmatic eruptions are indicated by solid circles, and explosive eruptions are indicated by horizontal bars above the data. Data gaps (i.e., no data) are indicated by horizontal bars beneath the axes.

seismicity $(>100 \mathrm{~km})$, and $(6)$ ground tilt. No systematic effects were noticed for atmospheric pressure, tides, or shallow seismicity except for a tidal correlation discussed by McNutt and Beavan [1981] for the 1974 minor eruption sequence. A strong correlation, however, is observed with long-period (annual) sea level fluctuations, which are caused by wind-stress-driven circulation in the Gulf of Alaska (see below). Second, tilt, deep seismicity, and relative sea level changes together have been used to constrain a modeled aseismic slip event at depth that may have separately affected volcanic activity during 1977-1980.

\section{Correlations with Sea Level}

The correlation between annual variations in sea level and eruptions at pavlof is shown schematically in Figure 4. The figure shows a 25-year (1950-1974) average of monthly mean sea level (corrected for atmospheric pressure) from two tide gauges, Kodiak $500 \mathrm{~km}$ to the ENE and Dutch Harbor $350 \mathrm{~km}$ to the wSW. A histogram of the number of Pavlof eruptions each month is superimposed. Histogram bars are solid for magmatic eruptions, during which the seismicity rate is approximately 2000 events per day, while they are open for explosive eruptions, during which the rate is approximately 200 events per day. Two small magmatic eruptions with less seismicity than the others are shown as half units on the histogram for september and October. All the magmatic eruptions (solid bars) occur in the fall/early winter, when sea level is rising or is near maximum. The sea level change is observed throughout the Gulf of Alaska [Ingraham et al., 1976; Reid and Mantyla, 1975; Reed and Shumacher, 1981] and is caused by 


\section{PAVLOF VOLCANIC TREMOR}
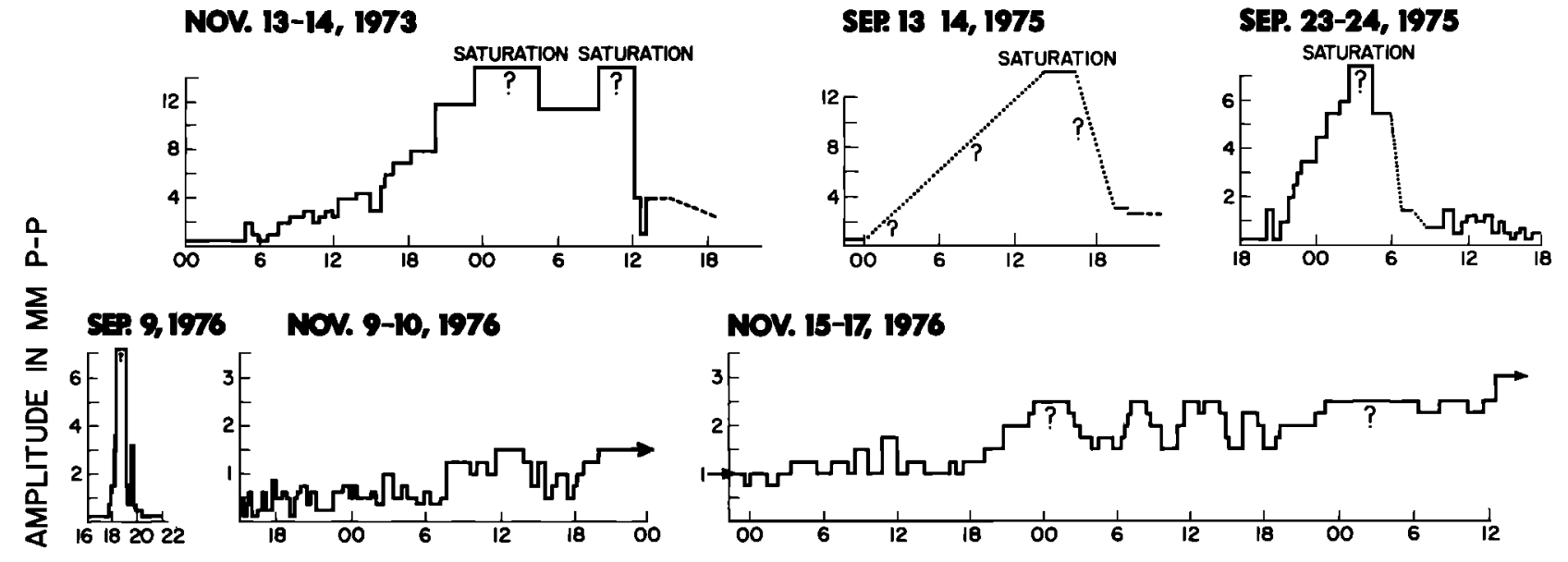

NOV. 15-17, 1976

NOV. 12-13, 1980

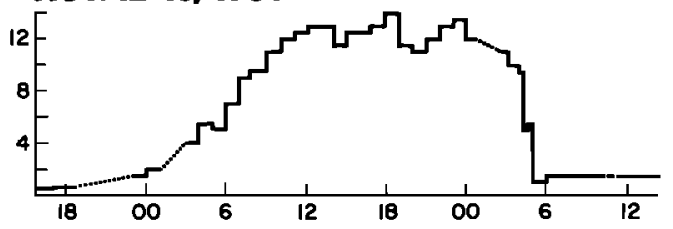

SEP. 26-27, 1981

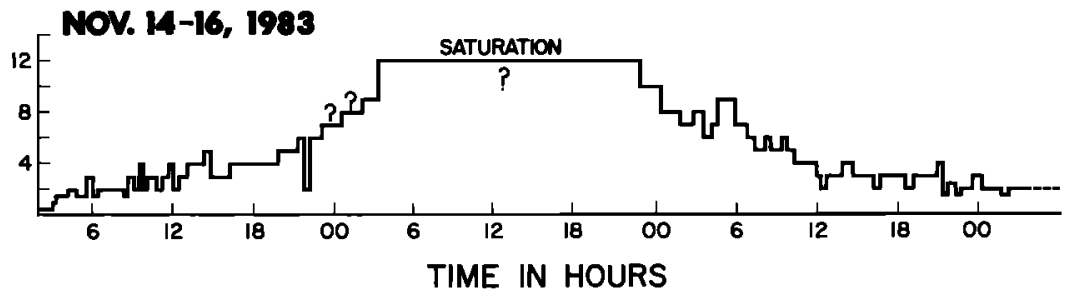

Fig. 3. Time series showing volcanic tremor amplitude during magmatic eruptions. Amplitudes are normalized. Numbers on horizontal axes are times in hours. Dotted where inferred (seismograms obscured or unavailable); dashed where intermittent.

wind-stress-driven surface circulation which sets up a subarctic cyclonic gyre in the Gulf of Alaska. Water is driven northward from $S-S W$ into the Gulf and flows out to the WSW along the continerital shelf of the Alaska Peninsula.

An additional tide gauge was installed at sand Point, which is closer to the volcano (about $80 \mathrm{~km}$ ), in 1972. Data from this gauge were used to calculate a correlation coefficient with the Pavlof seismicity data. Table 3 shows mean monthly sea level from the sand point tide gauge and mean monthly seismicity data for Pavlof for the time period 1973-1984. A simple linear regression was computed, and the correlation coefficient between the sea level and seismicity is 0.58 , which is significant at the 958 level. The same data can also be examined in a different way. In Figure 5 we show data from the Sand Point station low-pass filtered at 10 days, 4 months, and 8 months plotted against the Pavlof volcanic seismicity. The filtering is done with a zero-phase shift Butterworth filter which rolls off at 36 $\mathrm{dB} /$ octave above the cutoff frequency. We see that the eruptions do not correlate well with the sea level data when shorter periods are included (Figure 5, top). For example, the November 1973 eruption occurs at a sharp increase in sea height, the September 1975 eruptions occur just before a decrease in sea height, and the November 1986 eruption occurs roughly in the middle of a long-period increase in sea height. When only the longer-term component of the signal is considered (Figure 5 , bottom), the correlation improves in both amplitude and phase, and the shapes of the yearly curves approach the 25-year averages shown in Figure 4.

The correlation with long-term ( $>8$ month) sea level is a manifestation of the obvious approximately annual quasi-periodicity in the eruption data and does not necessarily imply a causal relationship. We have not, however, been able to determine any more likely causative factor for the observed eruption patterns. Below, we make some deterministic order of magnitude calculations that support the possibility that the sea level variations are 
TABLE 2. Parameters Used to Estimate Eruption Volumes

\begin{tabular}{|c|c|c|c|c|}
\hline Date & $\begin{array}{l}\text { Tremor Duration } \\
\text { Times Amplitude } \\
\mathrm{h} \times \mathrm{mm}\end{array}$ & $\begin{array}{l}\text { Tremor Duration } \\
\text { Times Amplitude } \\
\mathrm{h} \times \mathrm{mm}^{2}\end{array}$ & $\begin{array}{l}\text { Volume Estimated Using } \\
\text { Tremor Duration and } \\
\text { Amplitude Data from Columns } \\
2 \text { and } 3, \times 10^{6} \mathrm{~m}^{3}\end{array}$ & $\begin{array}{l}\text { Mean } \\
\text { Estimated } \\
\text { Volume*, } \\
x 10 \mathrm{~m}^{3}\end{array}$ \\
\hline Nov, 13-14, 1973 & 253 & 2839 & $4.8-7.9$ & 6.4 \\
\hline Sept. $13-14,1975$ & 187 & 1890 & $3.2-5.8$ & 4.5 \\
\hline Sept. 23-24, 1975 & 56 & 416 & $0.7-1.7$ & 1.2 \\
\hline Sept. 9,1976 & 15 & 72 & $0.1-0.4$ & 0.3 \\
\hline Oct. $18-22,1976$ (?) & 31 & 24 & $0.1-0.9$ & 0.5 \\
\hline Nov, $10-20,1976$ & 444 & 894 & $1.5-13.8$ & 7.6 \\
\hline Nov, $12-13,1980$ & 241 & 2753 & $2 \cdot 0-6.1+$ & $6.1+t$ \\
\hline Sept. $26-27,1981$ & 408 & 4704 & $8.9-12.6 \dagger$ & 10.8 \\
\hline Nov. $14-16,1983$ & 512 & 5296 & $9.0-15.9$ & 12.5 \\
\hline
\end{tabular}

*Values used for Table 4 and Figure 8 .

+Volume measured from photographs, pilot reports, and ash sample (see text).

$+\nmid$ Preferred value (see text).

partially responsible for the timing of eruptions.

\section{Rheological Implications}

We first consider the rheological implications of such a model on the crust and upper mantle in the vicinity of Pavlof, since it is clear that any correlation with sea level becomes insignificant on time scales less than several months. The available data do not allow us to formulate or test a quantitative rheological model; however, we are obliged to

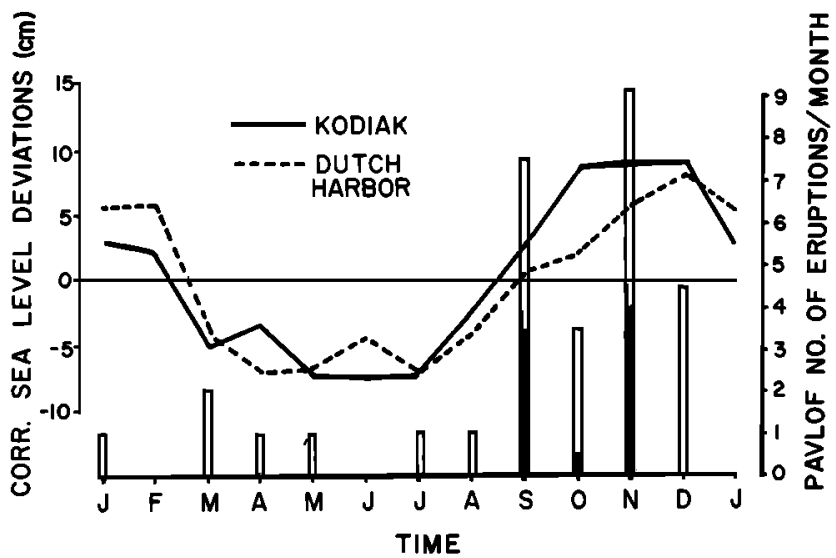

Fig. 4. Deviations in monthly mean-corrected (for atmospheric pressure) sea level from long-term mean (1950-1974) and number of eruptions per month at Pavlof Volcano

(1973-1984). Sea level data are from Ingram et a].. [1976]. Kodiak is approximately $500 \mathrm{~km}$ ENE of Pavlof, while Dutch Harbor is approximately $350 \mathrm{~km}$ WSW. Histogram bars are solid for magmatic eruptions and open for explosive eruptions. Seismicity for the magmatic eruptions (solid bars) is a factor of 10 greater than for the explosive eruptions (open bars). Note the correlation between eruptions and increased sea level in fall/winter. offer at least a conceptual model of the volcano's plumbing system. Results of a velocity inversion [McNutt and Jacob, 1986] show a low-velocity body at lower crustal depths ($20 \mathrm{~km}$ ) beneath Pavlof; this may extend much deeper (the lower boundary of the low-velocity body is not constrained). The low-velocity body may be either a magma chamber or a zone containing partial melt. In either case it is presumably open to a source region beneath it. Following the model of Wadge [1982, Figure 2, p. 4036], above this chamber may be a hot, and perhaps mechanically weakened, pathway for magma transport to a smaller subvolcanic reservoir, which may be connected to the summit vent via a conduit. This is a model only and does not necessarily represent Pavlof's plumbing system. The various components of the system may respond at different time scales to pressure variation and to flow of magma. Further, the bulk mechanical properties of the postulated system may differ from the properties of the

TABLE 3. Sand Point Sea Level and Pavlof Volcano Seismicity 1973-1984

\begin{tabular}{lcc}
\hline Month & $\begin{array}{l}\text { Monthly Mean } \\
\text { Sea Level* }\end{array}$ & $\begin{array}{l}\text { Monthly Mean } \\
\text { Number of Quakes }\end{array}$ \\
\hline January & 0.25 & 1,390 \\
February & 0.19 & 1,043 \\
March & 0.13 & 1,059 \\
April & 0.00 & 887 \\
May & 0.04 & 397 \\
June & -0.02 & 1,169 \\
July & -0.01 & 1,773 \\
August & 0.02 & 4,766 \\
September & 0.12 & 6,959 \\
October & 0.20 & 13,201 \\
November & 0.25 & 3,896 \\
December & 0.25 & \\
\hline
\end{tabular}

*In meters above arbitrary bench mark. 


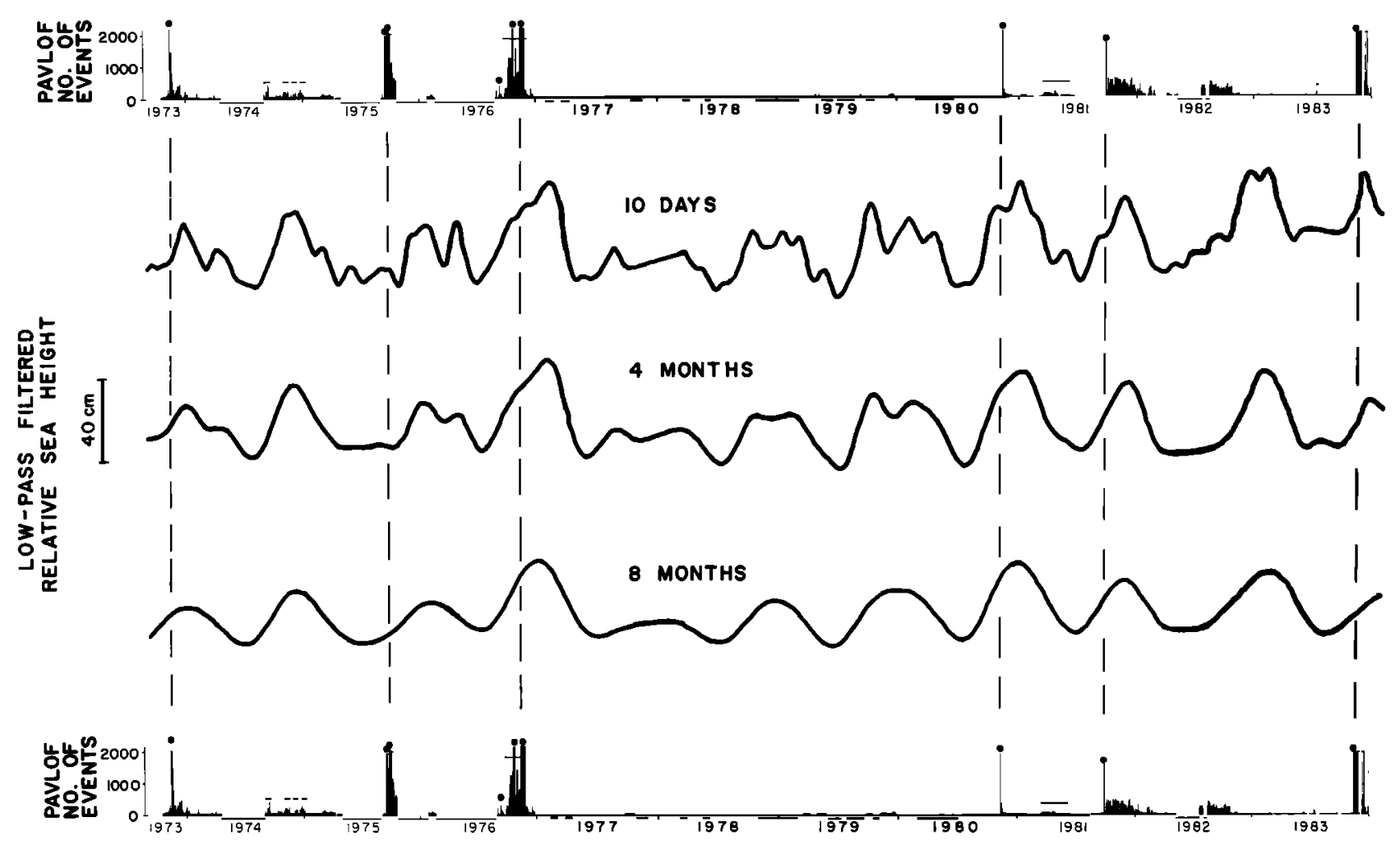

Fig. 5. Sea level at Sand Point $(80 \mathrm{~km}$ east of Pavlof) and Pavlof

seismicity/eruptivity. Sea level data are not corrected for atmospheric pressure. Sea level data are low-pass filtered at 10 days, 4 months, and 8 months, respectively. Note that when only the long-period components are considered, the correlation with the magmatic eruptions (vertical dashed lines) improves and that there do not appear to be correlations with shorter-term sea level variations.

components. The time series data suggest that at short periods the bulk system (of rock and magma) is elastic because it does not respond with movement of magma to the relatively large stress and strain changes due to tides and short-period atmospheric pressure variations. At longer periods, however, the system appears to be viscoelastic (by responding with flow of magma). Thus by postulating that the same system has quite different rheological properties at different time constants, we are able to reconcile the observation of no correlation between eruptions and tides (high amplitude, short period), but a significant correlation for wind-driven sea level fluctuations (lower amplitude, but long period). A measurement of the time constant for the transition from elastic to ductile behavior for a solid continuum is the Maxwell time, which is the ratio of viscosity to rigidity. Here we use 8 months (for which the correlation is consistent as shown in Figure 5) as the Maxwell time, calculate the rigidity from the shear wave velocity in the upper mantle, and estimate the viscosity. Numerically, we have

$$
\beta=\sqrt{\frac{\mu}{\rho}}
$$

where $\beta$ (S-wave speed) $=4.57 \times 10^{3} \mathrm{~m} \mathrm{~s}^{-1}$ (based on P-wave speed of $7.9 \times 10^{3} \mathrm{~m} \mathrm{~s}^{-1}$ in the upper mantle [Reyners and Coles, 1982] and a
$\mathrm{Vp} / \mathrm{Vs}$ ratio $=1.73)$, $\rho$ is density, for which we use $2900 \mathrm{~kg} \mathrm{~m}^{-3}$, and $\mu$ is rigidity. Solving this simple equation gives $\mu=6.45 \times 10^{10} \mathrm{~N}$ $\mathrm{m}^{-2}$. The viscosity $n$ is then given as

$$
\eta=\mu \tau
$$

where $\tau$ is Maxwell time. The calculated viscosity is $1.34 \times 10^{18} \mathrm{~Pa} s\left(1.34 \times 10^{19}\right.$ P), a value in close agreement with values obtained by Wahr and Wyss [1980] from measurements of Aleutian postseismic deformation, and up to 2 orders of magnitude lower than values found for other areas using techniques such as postglacial rebound of continental shields [Cathles, 1975; Peltier and Andrews, 1976; Bott, 1982, pp. 334-336]. The Maxwell time and viscosity given here are upper limits; since the system appears to be ductile at periods of 8 months, then the transition from elastic to ductile behavior must be at a shorter period. For our calculations we assumed that the upper mantle between the base of the crust (30-km depth) and the top of the Wadati-Benioff zone (100-km depth) is the material which is ductile at long-time constants. This material is aseismic throughout the shumagin region. Although no shallow earthquakes occur near Pavlof, they do occur in the adjacent crust and within the subducted slab; hence we assume both the crust and the slab are elastic. 


\section{Deterministic Estimates of Sea Level Effect}

We showed above (Figures 4 and 5 and Table 3 ) that the eruptions correlate in time with long-period sea level fluctuations. The polarity (increased ocean load at times of eruptions) is consistent with squeezing out magma, analogous to squeezing a tube of toothpaste. What remains is to demonstrate that the sea level fluctuations cause a strain change whose magnitude is large enough to produce the postulated effect. Since we have reliable estimates of the volume of erupted material for two of the eruptions, we next make a calculation of the annual changes in volume strain beneath the volcano which occur as a result of the seasonal variations in sea level and atmospheric pressure. Two (related) effects occur [Ingraham et al., 1976; Reed and Schumacher, 1981]. Atmospheric pressure is typically about $12 \mathrm{mbar}$ lower during fall and early winter than it is in the spring and summer. Sea level on the North Pacific continental shelf, after correction for the lower atmospheric pressure, is typically about $17 \mathrm{~cm}$ higher during fall and early winter (i.e., it is $-29 \mathrm{~cm}$ higher before the atmospheric pressure correction is made). The fall and winter increase in sea level is related to an increase in northward wind-stress-driven transports [Favorite, 1974] and to increased flow in the North Pacific subarctic cyclonic gyre [Reid and Mantyla, 1975]. Examination of the plots given by Ingraham et al. [1976] suggests that the winter increase in sea level is confined to the North Pacific continental shelf area. We will use this area in the loading calculations below; any error will be small, as the load stresses and strains are principally due to loads close to the volcano.

Between summer and winter, then, there is an increase in load on the North Pacific continental shelf, corresponding to $\sim 17 \mathrm{~cm}$ of water (after atmospheric correction), and a decrease in load on the Alaska Peninsula and island land masses, corresponding to $\sim 12 \mathrm{~cm}$ of water (-12-mbar air pressure). We define the amplitude distribution of these loads on a $0.10 \times 0.10^{\circ} \mathrm{grid}$ within $500 \mathrm{~km}$ of pavlof and calculate the volume strain at various depths in the vicinity of the volcano [e.g., Beavan, 1974; McNutt and Beavan, 1984]. The mass-loading Green's functions were calculated for various depths within a standard elastic earth model, using a method similar to Farrell's [1972]. For simplicity, to make an order-of-magnitude estimate, these calculations assume an elastic earth even though we assume elsewhere that a region beneath the volcano can behave viscoelastically.

Because the average volcano spacing is $40 \mathrm{~km}$, we assume that a volume defined by a $40 \times 40 \mathrm{~km}$ area centered on pavlof and extending from the base of the crust $(30 \mathrm{~km})$ to the Wadati-Beniof $\mathrm{f}$ zone $(\sim 100 \mathrm{~km})$ acts as a "feeder" volume for the volcano. The true magma generation and storage complex, which we call the "feeder" zone, probably includes structures with many different rheologies and geometries. These different rheologies and geometries could have a substantial effect on the distribution of stresses or strains resulting from a source such as ocean loading. In the absence of other information, however, we are obliged to use what we consider the simplest approximation. Hence we calculate the volume strain at points spaced $5 \mathrm{~km}$ apart in a $40 \times 40 \times 70 \mathrm{~km}^{3}$ box centered below the volcano; these values are averaged to obtain the mean volume strain. The result of the calculations is a mean compression of $1.6 \mathrm{x}$ $10^{-9}$. This strain results in a compressional volume change of $1.8 \times 10^{5} \mathrm{~m}^{3}$, which is about 2 times greater than the smallest eruption volumes and 50 times smaller than the largest (Table 2). However, no volcanoes within $70 \mathrm{~km}$ ENE or $110 \mathrm{~km}$ WSW of Pavlof have shown any signs of activity in the last 10 years, suggesting that the feeder volume, and thus the volume change, may be larger. A doubling of the feeder volume would more than double the corresponding volume change at depth. This is because the effects of ocean loading dominate those of atmospheric loading at points farther from the volcano, since these are mostly located below ocean rather than land. These calculations suggest that the volcano may be acting as a large-sized, long-period (damped) volumetric strain meter but that the lava volume is not simply the same as the compressional volume change at depth, as it would be in a perfect "toothpaste tube" analogy. It appears that the volcano responds to an increase in compressional stress in a triggering mode; that is, an eruption is more likely to start under conditions of increasing volumetric compression. Support for this view comes from the converse response of the volcano to a modeled slip event which we believe caused dilatation beneath the volcano. The volcano did not erupt for several years during this dilatational event.

\section{Effects of Tilt Reversal}

In this section we examine in detail the evidence for the tilt reversal, its likely areal extent, and the reasons why we believe its occurrence may have affected the volcano. Figure 6 shows a map view of all teleseismically recorded earthquake data for the Shumagin region. The deep events are clustered spatially just to the NE of Pavlof, and also roughly on strike with the Shumagin Islands themselves. Note that the only deep events recorded in this 250-km-long section of the arc are those within this cluster. Figure 7, updated from Beavan et al. $[1983,1984]$, shows these events displayed as a time series, along with tilt, microearthquake, and schematic eruption data. Seventy percent of all deep teleseisms and 908 of those deeper than $160 \mathrm{~km}$ occurred during the 3.5-year period during which the volcano was not erupting (1977-1980).

The tilt reversal itself (Figure 7 , top) occurred sometime between summer 1978 and summer 1980. Prior to 1978 the tilt rate measured by a line $200 \mathrm{~km}$ from the trench (SQH) was $-1.0 \pm$ $0.3 \mu \mathrm{rad} \mathrm{yr}^{-1}$ down toward the trench in the sense expected for interseismic loading of the overlying plate when coupled to the converging and descending Pacific plate. Since 1980, the mean tilt measured by two lines in approximately the same location (SQH and SDP) has been $-0.4 \pm$ 


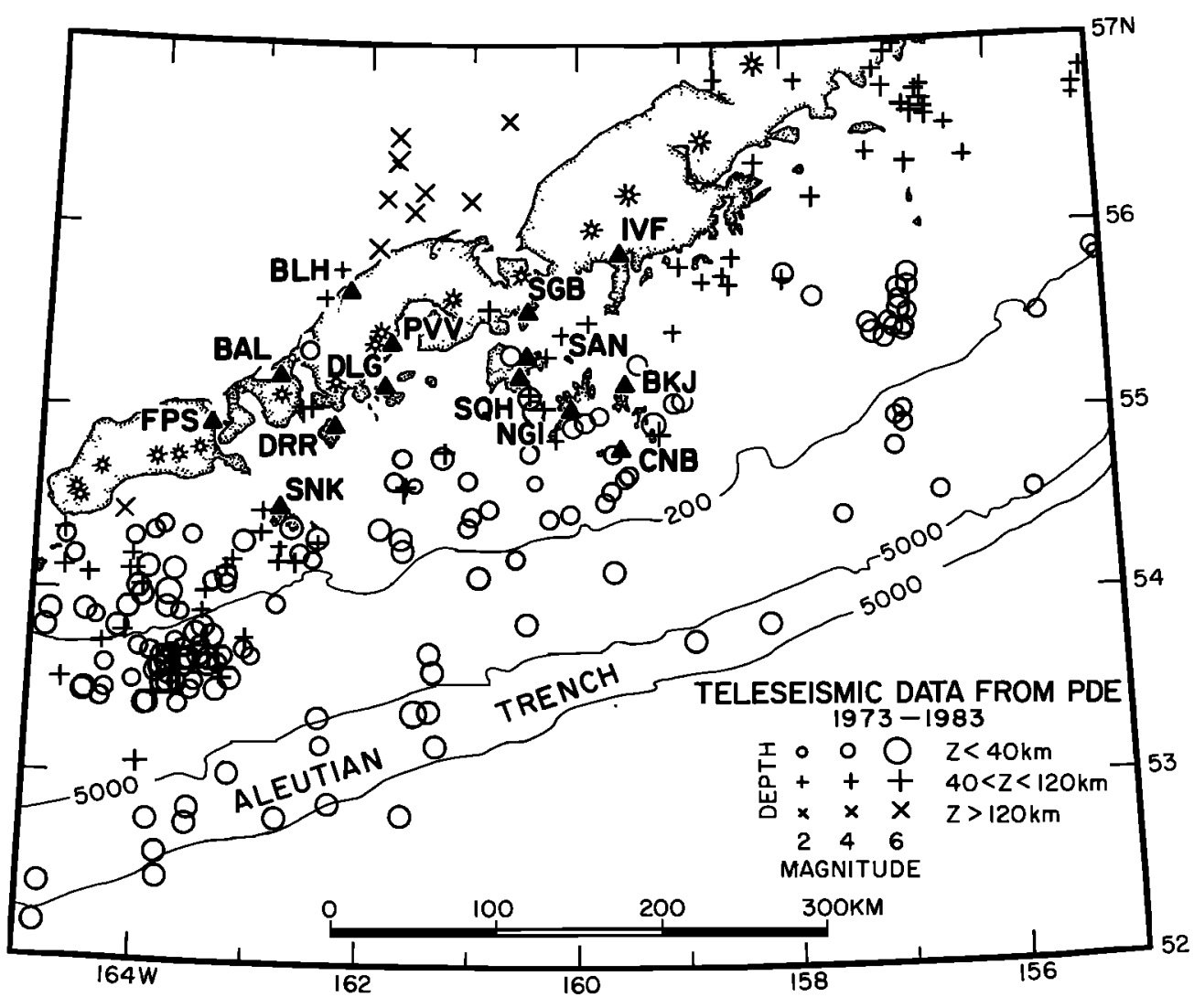

Fig. 6. Epicenter map of teleseismic data from PDE for the Shumagin region. All data from 1973-1983 are shown. Note that the only cluster of deep events is located in the back arc region NNE of Pavlof Volcano (NNE of station PVV). A time series for these events is displayed in Figure 7 [after Jacob and Hauksson, 1983].

$0.2 \mu \mathrm{rad} \mathrm{yr}^{-1}$ in the same direction. Between 1978 and 1980, however, there was a marked reversal of tilt direction. The two lines more remote from the trench indicate a tilt rate of $+2.7 \pm 0.5 \mu \mathrm{rad} \mathrm{yr}^{-1}$ down away from the trench. The changes in tilt rate in 1978 and in 1980 are significant above the 988 confidence level [Beavan et al., 1984, p. 4479]. During this same time period the microearthquake activity in the Shumagins changed; seismicity was higher during the tilt reversal and lower afterward. Beavan et al. [1983, 1984] modeled the tilt reversal as an aseismic slip event. They suggested that the observed tilt and sea level data could be fit with $80 \mathrm{~cm}$ of slip between $-80-$ and $-20-\mathrm{km}$ depth on a plane dipping 320 toward the volcanic axis. The slip event was modeled as a dislocation in an isotropic, homogeneous, linear elastic half-space [e.g., Hastie and Savage, 1970] having seismic velocities $\mathrm{Vp}=6.1 \mathrm{~km} \mathrm{~s}^{-1}$ and $\mathrm{vs}=3.5 \mathrm{~km}$ $\mathrm{s}^{-1}$. The model assumes that the slip is pure thrust and is confined to the $32^{\circ}$ dipping plane discussed above and that the final slip distribution is rectangular in areal extent, is of uniform offset, and measures $100 \mathrm{~km}$ along strike.

The spatial and temporal occurrence of the deep teleseisms (Figures 6 and 7 ) suggests that they are related to both the tilt reversal and to the cessation of volcanic activity at Pavlof. These events are significantly larger than all of the deep microearthquakes recorded in the same time period; hence the occurrence of the relatively few large events represents a greater strain energy release than that of all the small ones combined. We infer the spatial extent of the tilt reversal in a direction parallel to the trench from indirect observations: the two leveling lines which detected it are in the Shumagin Islands proper, separated by $10 \mathrm{~km}$ and at a distance of $90 \mathrm{~km}$ from Pavlof. The deep teleseisms themselves occur in a zone about $80 \mathrm{~km}$ wide (excluding the single event to the NE of the others). Further, the double-planed Benioff zone discussed by Reyners and coles [1982] does not extend across the entire 400-km-long Shumagin region. Their Figure 4 shows that none of the events composing the lower plane of the double-planed portion of the dipping seismic zone occur in a zone about $80 \mathrm{~km}$ wide roughly centered on the Shumagin Islands. More recent shumagin network data from 1979-1985 show that this pattern is temporally persistent [Taber and Hudnut, 1985]. This suggests possible anomalous mechanical properties within the subducted plate in the vicinity of the Shumagin Islands. From these indirect observations we speculate that the width over which the postulated slip event took place is probably about $80-100 \mathrm{~km}$. Pavlof itself sits just to the west of the shumagin Islands and just inside the western end of the cluster of deep teleseisms (Figure 6 ). 

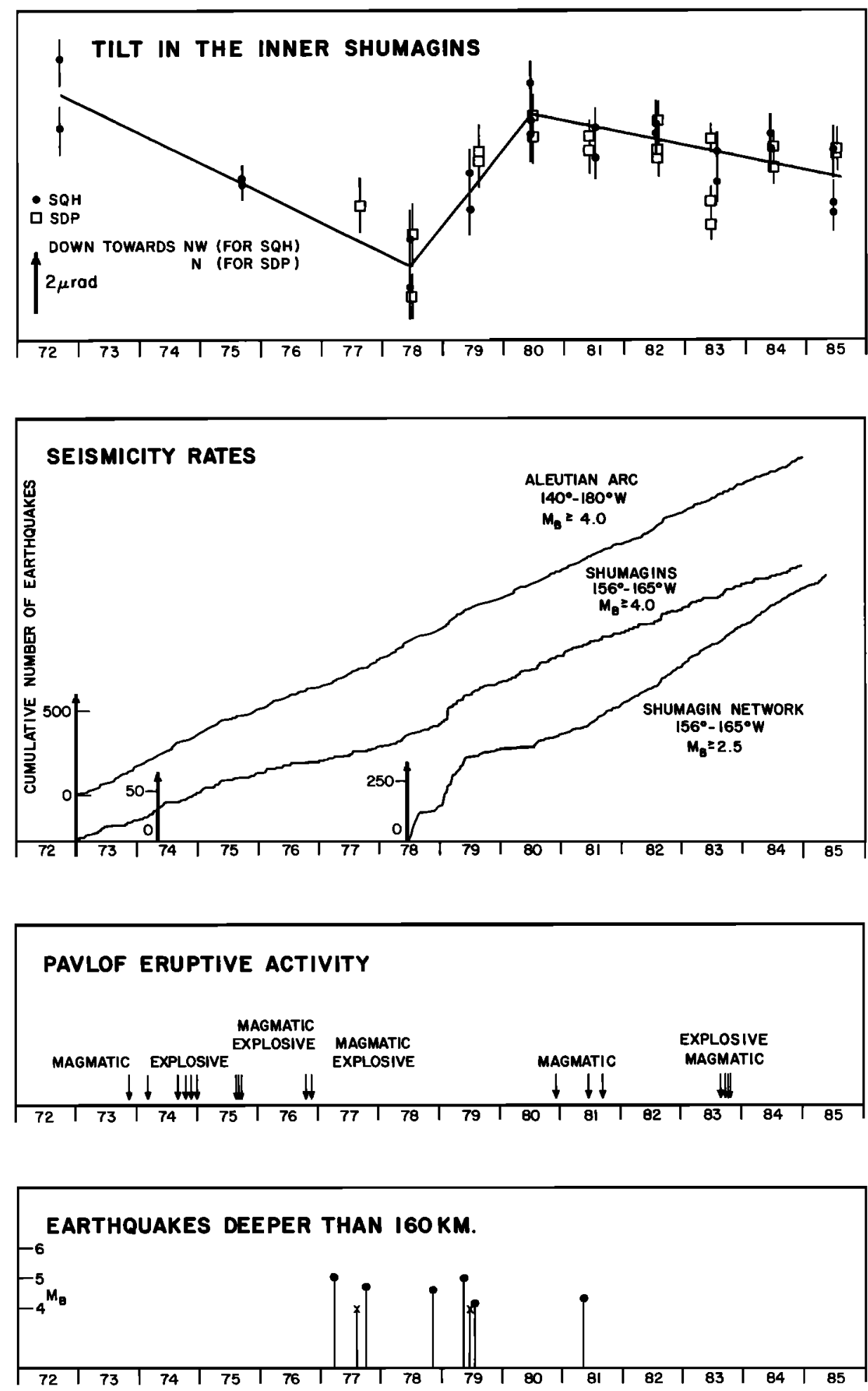

Fig. 7. Tilt, seismicity rates, Pavlof eruptive activity, and deep earthquakes in the shumagin region for the time period 1972-1985. An apparent tilt reversal took place on three level lines between 1978 and 1980. The tilt change is significant at the 988 level on two of the lines, and these are plotted here. The line drawn through the data is our interpretation of the tilt history in the inner Shumagin Islands. During the tilt reversal, the seismicity rate for microearthquakes was higher, Pavlof volcano was not erupting and exhibited very low seismicity, and most of the teleseismically recorded deep earthquakes occurred in a cluster NNE of Pavlof (see Figure 6). The estimated magnitude for complete reporting is 4.5 ; quakes plotted with a cross had no magnitude assigned in the PDE catalog. Figure updated from Beavan et a1. [1983]. 
We calculate the volume change predicted by this model in the $40 \times 40 \times 70 \mathrm{~km}^{3}$ feeder volume discussed above, again ignoring any viscoelastic behavior. Expressions for the displacements at depth due to a dislocation in a linear elastic half-space are given by Mansinha and Smylie [1971]. We differentiated these to generate corresponding expressions for stress and strain. Using elastic parameters $\lambda=\mu=8$ $x 10^{10} \mathrm{~N} \mathrm{~m}^{-2}$, the extensional strain is 2.3 $x 10^{-7}$ and the volume increase in the box is $26 \times 10^{6} \mathrm{~m}^{3}$. As above, if the volume of the feeder zone is larger, the volume increase will also be larger. If the western edge of the reverse slip episode is farther west than in our model, this will also somewhat increase the estimated volume change. We speculate that the net volume increase at depth caused by the slip event is the reason the volcano did not erupt between 1977 and 1980. If so, then again the volcano appears to be behaving as a large, long-period volumetric strain meter.

\section{Discussion}

\section{Magma Generation Rate}

In Figure 8 (top), we plot the cumulative volume of erupted material (estimated from tremor duration and amplitude) versus time. Points generated by projecting individual cumulative volumes to the times of successive episodes (open symbols) have been fitted with a line by least squares; the slope of $3.1 \times 10^{6}$ $\mathrm{m}^{3} \mathrm{yr}^{-1} \quad\left(=0.10 \mathrm{~m}^{3} \mathrm{~s}^{-1}\right)$ represents the long-term ( 11 years) rate of increase in cumulative erupted volume with time. This estimate is within a factor of 2 , since estimates of eruption volumes are accurate to only about a factor of 2. It can be seen that the slopes of the 1973-1976 and 1980-1983 segments of data are steeper than the long-term rate and similar to each other, but a discontinuity occurs from 1977 to 1980 . If the volume change caused by strain resulting from the tilt reversal is added, as in Figure 8 (bottom), then the slope for the entire plot falls between the values of the 1973-1976 and 1980-1983 segments. The least squares slope for the open symbols is $7.2 \times 10^{6} \mathrm{~m}^{3} \mathrm{yr}^{-1}$ $\left(0.22 \mathrm{~m}^{3} \mathrm{~s}^{-1}\right)$, within a factor of 2 . The correlation coefficient for the long-term rate (open symbols) improves from 0.974 for Figure 8 (top) to 0.994 for Figure 8 (bottom); thus not only does the slope increase when the volume change caused by the tilt reversal is added, but the fit of the data improves as well. (Note that the slope of Figure 8 (bottom) no longer represents cumulative erupted volume; data include eruptions (solid circles) and the tilt reversal (solid square) for which a volume increase at depth occurred but nothing erupted.) Figure 8 is plotted using a volume change for the tilt reversal episode corresponding to a source region $40 \times 40 \times 70$ $\mathrm{km}^{3}$, though the region may be larger, as discussed above. All rates (with and without the tilt reversal) are slightly lower than the values of $0.3-0.9 \mathrm{~m}^{3} \mathrm{~s}^{-1}$ given by Wadge [1982] for his 11 most reliable output rates for steady state volcanism. Wadge defines steady

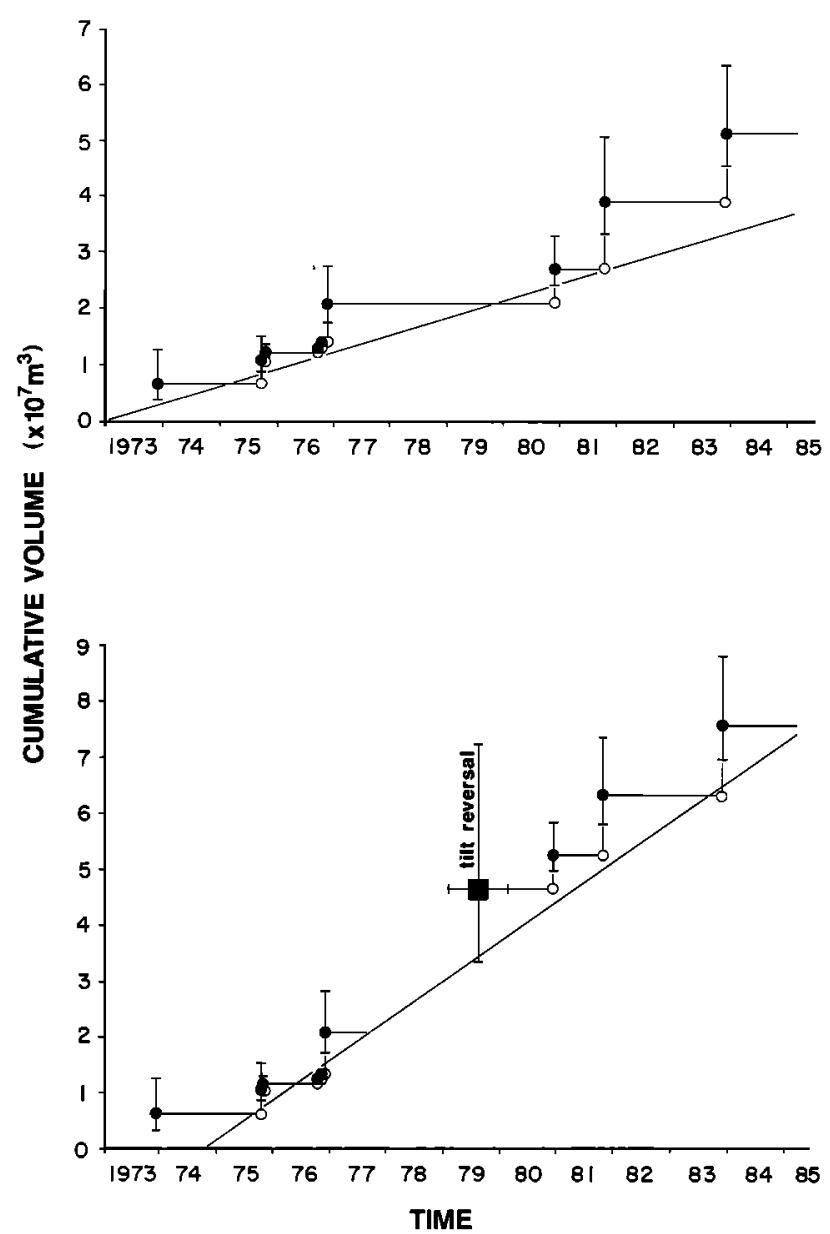

Fig. 8. Cumulative volume of erupted material versus time. (Top) offset of either 1973-1976 or 1980-1983 portions during the 1977-1980 quiescent period. (Bottom) Volume change corresponding to tilt reversal is included. Volume of tilt reversal was computed using source region $40 \times 40 \times 70 \mathrm{~km}^{3}$ (see text).

state volcanism as that for which magma is supplied and erupted at a constant rate (averaged over several months or years), although the eruption history in detail may be a series of discrete events. Pavlof is a particularly clear example of the case of a constant long-term ( 11 years) rate made up of a series of discrete (and quite similar) eruptions. We next make a simple mass blanace calculation for the convergent plate boundary near Pavlof. The motivation for this is to facilitate comparison with other areas and to elucidate further the volcano's role in the subduction process. The plate convergence rate for the shumagin area is $75 \mathrm{~mm} \mathrm{yr}^{-1}$ [Minster and Jordan, 1978]. Thus the volume of crust being fed into the subduction zone in the vicinity of Pavlof in 1 year is $75 \mathrm{~mm}$ (rate) $\mathrm{x}$ $40 \mathrm{~km}$ (width) $\times 10 \mathrm{~km}$ (thickness) $\simeq 3 \times 10^{7}$ $\mathrm{m}^{3}$, or about 6 times greater than the average amount erupted annually. Data presented by wadge [1984] indicate values ranging between about 28 and $3 \%$ for the Lesser Antilles and 4-8\% for Central America. Thus the value for Pavlof 
( $16 \%$ ) seems high; if the source area or feeder zone is larger, however, this difference can be reconciled. Kay [1977] has shown that at most, only about $5-10 \%$ of the subducted crust is melted during andesite genesis (that is, erupted lavas are composed of $>90 \%$ melt derived from the upper mantle and at most 108 material from the subducted crust). This implies that the volume of crust subducted greatly exceeds that which is recycled as fresh magma (by a factor of $>60$ for Pavlof). The mass balance calculation shown above is therefore a simplification; the comparison with the Lesser Antilles and Central American subduction zones is valid only if the melt percentages as determined by Kay are also comparable.

\section{Volcano Formation}

The volume of Pavlof volcano is $-35 \mathrm{~km}^{3}$ (T. Miller, personal communication, 1986); at a rate of $3.1 \times 10^{6} \mathrm{~m}^{3} \mathrm{yr}^{-1}$, it would thus take 11,000 years to build the edifice, assuming no erosion, no loss of ash, and that this rate has persisted. This is a youthful age for an arc volcano, but taking account of erosion and ash loss, Pavlof could be older. Also, Pavlof may have been unusually active over the 11 years from 1973 to 1984; hence the rate at which material has been erupted during this recent time span may be higher than average. All historic eruptions at Pavlof are Volcano Explosivity Index 2 or 3 [Simkin et al., 1981] and are thus similar in character and size to those of the last 11 years. Older eruptions, however, may have been of different size than these.

\section{Time-Predictable Model}

Linear regressions were made between the volume of each eruption and the time in days until the next eruption and between the volume and the time since the previous eruption (Table 4). The correlation coefficients are 0.65 and 0.37 , respectively. Only the former is significant at the 958 level. Thus data shown in Figure 8 support a time-predictable model for volcanism at Pavlof [e.g., Shimazaki and Nakata, 1980; Bacon et al., 1981]. That is, if we

TABLE 4. Eruption Volumes, Time Before Next Eruption, and Time After Last Eruption

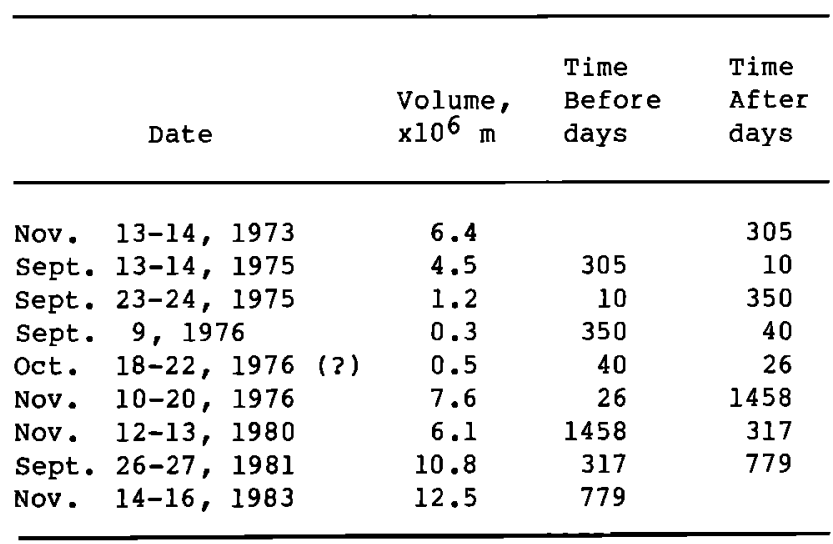

understand the physical processes taking place (e.g., long-term rate of magma supply), we can in theory predict the time of the next eruption. In the present case, if we know the volume of an eruption, we can then estimate the time until the next eruption. We refrain from making such a prediction, however, because the time-predictable aspect of Pavlof's behavior is only one part of the analysis. The models discussed in this paper require analysis of tilt, sea level, and seismic data as well. While we do not address details of magma formation, we suggest it is occurring at an approximately constant rate. Our model suggests that magma then erupts preferentially when a compressive volume change at depth is induced by sea level variations. The postulated aseismic slip event is viewed as a perturbation which caused a net volume increase at depth, 'nterrupting the normal activity.

\section{Summary and Conclusions}

In this paper we have synthesized the available geophysical data pertaining to the eruptive activity of Pavlof Volcano, and data are presented concerning basic features of the eruptions and accompanying seismicity. Rather than studying the volcano as an isolated entity, however, we have treated it as an active participant in the complex tectonic processes of subduction. The available data have led us to concentrate on the mechanical aspects of the volcano's behavior, including volumetric and rheologic considerations.

Pavlof's eruptive pattern is unusual in that all the major eruptions between 1973 and 1984 occurred in the fall and early winter. This fact led us to evaluate time series of all other available geophysical data. Ocean load effects, for which we performed deterministic, order of magnitude calculations, have the proper polarity and produce volume changes at depth that are in reasonable agreement $(2-2008)$ with the measured or estimated eruption volumes. We thus tentatively conclude that seasonal variations in sea level may be triggering or modulating the times of eruptions. During a 3-year period of no eruptions, an episode of anomalous tectonic activity occurred in the shumagin Islands region. A postulated aseismic slip event, whose parameters were deduced and modeled independently of the volcanic or ocean loading data, provides the most satisfactory explanation for the anomalous tectonic activity. The postulated aseismic slip event has the proper polarity, and deterministic calculations show that it would produce volume changes at depth within about a factor of 2 of those determined from long-term magma production rates. We thus tentatively conclude that the postulated aseismic slip event may have interrupted the normal magma supply processes.

These two principal conclusions, that the separate, independent phenomena of ocean loading and the postulated slip event may modulate the activity of Pavlof Volcano on different temporal and spatial scales, suggest that the volcano may also respond to other ambient stress changes. Pavlof is located roughly in the middle of the Shumagin seismic gap, and we speculate that 
prior to, during, and after the expected large earthquake, the activity of the volcano may change. Further, if future tilt measurements show that another reversal is taking place (as in 1978-1980), it may be possible to predict an eruption at pavlof after the period of reversed tilt is over (e.g., 1980). Major earthquakes, large eruptions, or other phenomena in adjacent segments of the Alaska-Aleutian arc may also cause changes in the ambient stress field and hence modulate Pavlof's eruptive activity.

The volcano was in a period of repose, similar to 1977-1980, from December 1984 to April 1986. (The first version of this paper was completed and submitted for publication in March 1985.) New eruptions began in April 1986, and preliminary data reduction indicates that stronger activity occurred from April 12 to 19. May 26 to September 1, September 24 to october 5, and November 6 to 19 . The timing of the latter two periods of stronger activity supports the hypotheses of this paper, while the timing of the former two does not. It appears that eruptions are continuing as of this rewriting (December 1986). The initial phase of the April 1986 eruption appears to have been more explosive and more energetic than were eruptions during 1973-1984, and volcanic tremor amplitude was higher as well. A thorough study and comparison of the 1986 activity with the previous activity have not yet been completed. Also, it has not been possible to study in detail all the appropriate sea level, tilt, and seismic data to determine if aseismic slip or some other process occurred. Therefore we cannot yet determine whether the new data support or contradict our model.

Improved knowledge of the velocity structure and rheology of the volcano and the surrounding Shumagin Islands region may eventually permit more sophisticated modeling than was posible here. Also, tilt measurements on the volcano itself would help constrain the depths of magma transport and storage. Until such knowledge of velocity structure, rheology, and local tilt is available, the conclusions of this paper must remain speculative. It is hoped, however, that the synthesis of ideas presented may guide future research at Pavlof and may also stimulate similar studies at other volcanoes.

The quasi-periodicity of eruptions and apparent sensitivity to small changes in ambient stresses and strains may be unique to pavlof volcano, but if studies elsewhere yield similar results, then it may eventually be possible to formulate a general quantitative model of the mechanical factors controlling eruptions of arc volcanoes.

Appendix: Details of Eruption volume Calculations

E. Hauksson (personal communication, 1981) took about 12 color slides of the 1981 lava flow including views from a helicopter and the ground at a variety of angles, from distances of about $20 \mathrm{~m}$ to $5 \mathrm{~km}$. Four of these slides were enlarged to $5 \times 7$ inch glossy prints for further analysis. The photographs show a lava flow extruded from the vent about $100 \mathrm{~m}$ below the summit (elevation $2518 \mathrm{~m}$ ) down the NNW flank to about the $600-m$ level, for a length of about 4.3 $\mathrm{km}$ (see also Scientific Event Alert Network (SEAN) [1981]). The lava flow is about $2.3 \mathrm{~km}$ wide at its widest and lowermost end, and it covers about one third of the triangular area formed by the summit vent and the two edges of the flow at its distal end. The area covered by the lava flow is therefore approximately $1.6 \mathrm{x}$ $10^{6} \mathrm{~m}^{2}$. The thickest portion of the flow front was 6-7 $\mathrm{m}$, but the average thickness was about one half of that, or 3-3.5 m. Multiplying the area times this thickness gives a total volume of 4.8-5.6 $\times 10^{6} \mathrm{~m}^{3}$ for the lava flow. A Reeve Aleutian Airways pilot flying near Pavlof at 1900 UT on september 26, 1981, observed a black eruption column and estimated the altitude of its top at roughly 6-7 km. He also reported incandescent material on the west flank [SEAN, 1981]. For the september 1981 eruption, the reports and photographs taken by the field crew are superior to the pilot reports.

A crude ash volume estimate was made from a single observation of $4-\mathrm{cm}$ ash accuinulation on the deck of a fishing boat in Pavlof Bay, 10-15 $\mathrm{km}$ to the east (downwind) [SEAN, 1981]. A log-log plot was made of maximum ash thickness in centimeters versus distance in kilometers for 15 eruptions with known volumes and of various sizes [see Jacob and Hauksson, 1983, p. 136], and the observation at Pavlof of $4 \mathrm{~cm}$ (assumed to be a maximum) of ash at a distance of 10-15 km was compared with the plot. While such observations depend critically on wind direction and eruption type, ash from four other eruptions had a similar thickness $(2-7 \mathrm{~cm})$ at distances of 10-15 km. The corresponding volumes of these are $10^{7} \mathrm{~m}^{3}$ for Mount St. Helens, 1842 [Crandell and Mullineaux, 1978]; $1.4 \times 10^{7}$ $\mathrm{m}^{3}$ for Mount st. Helens, May 25,1980 [Sarna-Wojcicki et al., 1982]; $1.7 \times 10^{7} \mathrm{~m}^{3}$ for Cerro Negro, 1968 [Taylor and stoiber, 1973; Rose et al., 1973]; and $7 \times 10^{7} \mathrm{~m}^{3}$ for Cerro Negro, 1971 [Rose et al., 1973]. The latter value was excluded because the ash thickness for this eruption increased drastically between a distance of $6.5 \mathrm{~km}$ and the vent. Volumes for the other three range between 1 and $1.7 \times 10^{7}$ $\mathrm{m}^{3}$ of ash. We therefore infer that the volume of ash for the september 1981 Pavlof eruption was within this same range. The error is unknown and could be large. The fishing boat on which the ash was sampled was almost directly downwind (E) of the vent, so the ash thickness obtained on the boat was probably near the maximum for this eruption at this distance. The ash thicknesses for the other eruptions discussed above were also maximums.

Reeve Aleutian Airways pilot E. Skinner (written communication, 1980) reported on the 1980 eruption that "A basaltic flow had progressed down the north side of the mountain...to approximately 1,000-1,500 feet down the mountain...until it ran into a "chimney" or indentation of terrain and was funneled down to where the mountain flared out..." (about $3.5 \mathrm{~km}$ ). G. Roberts (personal communication, 1980) of the Cold Bay Weather station reported a lava flow during the eruption about one third of the way down the mountain (about $1.5 \mathrm{~km}$ ) when viewed through binoculars. (The day was "remarkably clear" according to 
Skinner.) Lamont-Doherty Geological Observatory technician, L. Skinta (personal communication and written communication, 1981) provided a description and sketch map showing a narrow lava flow (about $200 \mathrm{~m}$ wide) extending from several hundred meters below the summit vent to where the mountain changes slope (about $3.5 \mathrm{~km}$ ), at which point the flow flares out and stops. The flow was estimated to be about $4 \mathrm{~m}$ thick. Thus the estimated volume is length $\left(1.5-3.5 \times 10^{3}\right.$ m) times width $\left(2.0 \times 10^{2} \mathrm{~m}\right)$ times thickness (4 m), or $1.2-2.8 \times 10^{6} \mathrm{~m}^{3}$. The latter value is preferred because both the skinner and skinta estimates confirm it. E. Skinner (written communication, 1980) reports a column of ash and steam to more than $6.5 \mathrm{~km}$ on November 11,1980 , and satellite images on November 12, 1980, reveal a plume 8-11 km above sea level [SEAN, 1980]. The September 1981 plume reached a height of $10.5 \mathrm{~km}$ above sea level [SEAN, 1981].

Acknowledgments. We thank $k$. Jacob and $C$. Scholz for critical review; L. Sykes, R. Bilham, $M$. Carr, and $R$. Cember for informative discussions; and J. Mori, K. Hurst, and T. Boyd for stimulating comments. $R$. Bongiorno, A. Dobrovolsky, and L. Murphy repeatedly typed the manuscript. R. Nagao, M. Luckman, M. Braun, and C. Peppin assisted with preparing the figures. This research was supported by the Department of Energy contract DE-FG-02-84-ER13221. One of us (R.J.B.) was supported by the National Aeronautical and Space Administration under grants NAS-5-27237 and NAG-5-799.

Lamont-Doherty Geological Observatory contribution 4178 .

\section{References}

Bacon, C. R., R. Macdonald, R. L. Smith, and P. A. Baedecker, Pleistocene high-silica rhyolites of the coso volcanic field, Inyo County, California, J. Geophys. Res., 86 , $10,223-10,241,1981$.

Beavan, R. J., Some calculations of ocean loading strain tides in Great Britain, Geophys. J. R. Astron. Soc., 38, 63-82, 1974.

Beavan, R. J., E. Hauksson, S. R. McNutt, R. Bilham, and K. H. Jacob, Tilt and seismicity changes in the Shumagin seismic gap, science, 222, 322-325, 1983 .

Beavan, R. J., R. Bilham, and K. Hurst, Coherent tilt signals observed in the Shumagin seismic gap: Detection of time-dependent subduction at depth, J. Geophys. Res., 89, 4478-4492, 1984.

Bott, M. H. P., The Interior of the Earth: Its Structure, Constitution and Evolution, 403 pp., Edward Arnold, London, 1982.

Cathles, L. M., The Viscosity of the Earth's Mantle, Princeton University Press, Princeton, N. J., 1975.

Crandell, D. R., and D. R. Mullineaux, Potential hazards from future eruptions of Mt. St. Helens Volcano, Washington, U.S. Geol. Surv. Bull., 1383-C, Cl-C26, 1978.

Farrell, w. E., Deformation of the earth by surface loads, Rev. Geophys., 10, 761-797, 1972 .

Favorite, F., Flow into the Bering sea through Aleutian Island passes, in Oceanography of the Bering Sea, edited by D. W. Hood and $E$. J. Kelly, pp. 3-37, Institute of Marine Science, University of Alaska, Fairbanks, 1974 .

Hastie, L. M., and J. C. Savage, A dislocation model for the Alaska earthquake, Bull. Seismol. Soc. Am., 60, 1389-1392, 1970 .

Ingram, W. J., Jr., A. Bakun, and F. Favorite, Physical oceanography of the Gulf of Alaska, Environmental Assessment of the Alaskan Continental Shelf, vol. 2, Principal investigator's reports, April-June 1976, pp. 491-624, Environ. Res. Lab., Boulder, Colo., 1976.

Jacob, K. H., and E. Hauksson, A seismotectonic analysis of the seismic and volcanic hazards in the Pribilof Islands-Eastern Aleutian Islands region of the Bering sea, final report, contract NOAA 03-5-022-70, 224 pp., Lamont-Doherty Geol. Observ. of Columbia Univ., Palisades, N. Y., 1983.

Kay, R. W., Geochemical constraints on the origin of Aleutian magmas, in Island ArCs, Deep Sea Trenches, and Back-Arc Basins, Maurice Ewing Ser., vol. 1, edited by $M$. Talwani and W. C. Pitman, pp. 229-242, AGU, Washington, D. C., 1977.

Mansinha, L., and D. E. Smylie, The displacement fields of inclined faults, Bull. Seismol. Soc. Am., 61, 1433-1440, 1971 .

McNutt, S. R., The eruptive activity, seismicity, and velocity structure of Pavlof volcano, eastern Aleutians, Ph.D. thesis, 202 pp., Columbia Univ., New York, 1985.

McNutt, S. R., Observations and analysis of B-type earthquakes, explosions, and volcanic tremor at Pavlof Volcano, Alaska, Bull. Seismol. Soc. Am., 76, 153-175, 1986 .

McNutt, S. R., and R. J. Beavan, volcanic earthquakes at Pavlof Volcano correlated with the solid earth tide, Nature, 294, 615-618, 1981.

McNutt, S. R., and R. J. Beavan, Patterns of earthquakes and the effect of solid earth and ocean load tides at mount St. Helens prior to the May 18, 1980, eruption, J. Geophys. Res., 89, 3075-3086, 1984 .

McNutt, S. R., and K. H. Jacob, Determination of large-scale velocity structure of the crust and upper mantle in the vicinity of Pavlof Volcano, Alaska, J. Geophys. Res., 91 , 5013-5022, 1986.

Minakami, T., Fundamental research for predicting volcanic eruptions, I, Earthquakes and crustal deformations originating from volcanic activities, Bull. Earthquake Res. Inst. Univ. Tokyo, 38, 497-544, 1960.

Minster, J. B., and T. H. Jordan, Present-day plate motions, J. Geophys. Res.., 83 , 5331-5354, 1978 .

Peltier, W. R., and J. T. Andrews, Glacial-isostatic adjustment, I, The forward problem, Geophys. J. R. Astron. Soc., 46 , 605-646, 1976 .

Reed, R. K., and J. D. Schumacher, Sea Level variations in relation to coastal flow around the Gulf of Alaska, J. Geophys. Res., $\underline{86}$, 6543-6546, 1981.

Reid, J. L., and A. W. Mantyla, on the seasonal variation of sea elevations along the coast of the northern North Pacific Ocean 
(abstract), EOs Trans. AGU, 56, 1009, 1975. Reyners, M., and $K$. S. Coles, Fine structure of the dipping seismic zone and subduction mechanics in the Shumagin Islands, Alaska, J. Geophys. Res., 87, 356-366, 1982.

Rose, W. I., Jr., S. Bonis, R. E. Stoiber, M. Keller, and T. Bickford, Studies of volcanic ash from two recent Central American eruptions, Bull. Volcanol., 37, 338-364, 1973.

Rose, W. I., Jr., A. T. Anderson, Jr., L. G. Woodruff, and S. B. Bonis, The October 1974 basaltic tephra from Fuego volcano: Description and history of the magma body, J. Volcanol. Geotherm. Res., 4, 3-53, 1978.

Sarna-Wojcicki, A. M., S. Shipley, R. B. Waitt, Jr., D. Dzurisin, and S. M. Wood, Areal distribution, thickness, mass, volume and grain size of air-fall ash from the six major eruptions of 1980, The 1980 Eruptions of Mt. St. Helens, Washington, U.S. Geol. Surv. Prof. Pap., 1250, 577-600, 1982 .

Scientific Event Alert Network, Pavlof Volcano, 4, SEAN Bull., 5 (11), Smithson. Inst., Washington, D. C., 1980 .

Scientific Event Alert Network, Pavlof Volcano, 3, SEAN Bull. 6(9), Smithson. Inst., washington, D. C., 1981.

Shimazaki, K., and T. Nakata, Time-predictable recurrence model for large earthquakes, Geophys. Res. Lett., 7, 279-282, 1980.

Simkin, T., L. Seibert, L. McClelland, D. Bridge, C. Newhall, and J. H. Latter, Volcanoes of the World, 233 pp., Hutchinson Ross, Stroudsburg, Pa., 1981.

Sventek, P., Shishaldin-Pavlof volcanic activity, 31 October, 1975, Event 74-75, Cent. for Short-Lived Phenomena, Cambridge, Mass., 1975.

Sykes, L. R., J. B. Kisslinger, L, House, J. N. Davies, and K. H. Jacob, Rupture zones and repeat times of great earthquakes along the

Alaskan-Aleutian arc, 1784-1980, in

Earthquake Prediction: An International Review, Maurice Ewing Ser., vol. 4, edited by D. W. Simpson and P. G. Richards, pp. 73-80, AGU, washington, D. C., 1981.

Taber, J. J., and K. W. Hudnut, A transition from a single to a double Benioff zone near the Shumagin Islands, Alaska, Eos Trans. AGU, $66,958,1985$.

Taylor, P. S., and R. E. Stoiber, Soluble material on ash from active Central American volcanoes, Geol. Soc. Am. Bul1., 84 , 1031-1042, 1973 .

wadge, G., Steady state volcanism: Evidence from eruption histories of polygenetic volcanoes, J. Geophys. Res., 87, 4035-4049, 1982.

Wadge, G., Comparison of volcanic production rates and subduction rates in the Lesser Antilles and Central America, Geology, 12, 555-558, 1984 .

Wahr, J., and M. Wyss, Interpretation of postseismic deformation with a viscoelastic relaxation model, J. Geophys. Res., 85, $6471-6477,1980$.

R. J. Beavan, Lamont-Doherty Geological Observatory of Columbia University, Palisades, NY 10964.

S. R. McNutt, California Division of Mines and Geology, 630 Bercut Drive. sacramento, CA 95814 .

(Received April 1, 1985; revised February 24, 1987; accepted May 4, 1987.) 